\title{
The sacoglossans (Gastropoda Heterobranchia) of the central- eastern coast of Sicily (Ionian Sea)
}

\author{
Andrea Lombardo* \& Giuliana Marletta \\ Department of Biological, Geological and Environmental Sciences, University of Catania, 95124 Catania, Italy \\ *Corresponding author, email: andylombardo94@gmail.com
}

\begin{abstract}
The sacoglossans are a group of marine heterobranchs, distributed in tropical and temperate waters, which are specialised in sucking the cellular fluids of siphonal green algae and other macroalgae. In the present study all the species detected along the central-eastern coast of Sicily from 2017 to the beginning of 2021 are here reported. For each species, observations on morphology, abundance, location, depth, substrates, habitats, seasonality and further remarks were carried out. Through this research, it was highlighted that along the centraleastern coast of Sicily there is almost the $43 \%$ of all Mediterranean (including the Black Sea) sacoglossan species. Consequently, although this area is relatively small, it presents a high level of biodiversity regarding this group of gastropods.
\end{abstract}

KEY WORDS Phytobenthos; Marine Heterobranchia; Sacoglossa; Sea slugs; Sicily

Received 13.04.2021; accepted 30.07.2021; published online 14.09.2021

\section{INTRODUCTION}

One of the most peculiar and interesting group of marine molluscs is the super-order Sacoglossa (Gastropoda Heterobranchia), including about 300 species, with a size comprised between 0.2 to 6 $\mathrm{cm}$, and distributed worldwide in the photic zone of tropical and temperate waters (Jensen, 2007). The term "Sacoglossa" (also "Ascoglossa") comes from the occurrence of a structure called "sacus" or "ascus" in all members of this group. In this organ, the old and not anymore used teeth of the radula are conserved (Händeler, 2010). In the sacoglossans, the radula is uniseriate and only a tooth (the leading tooth) is used in feeding. The radula is constituted by an ascending limb, which presents new and not yet in use teeth, the leading tooth, and the descending limb that takes the old and not anymore used teeth toward the "sacus/ascus", where they will be stored for all the animal's life (Händeler, 2010). Almost all sacoglossans feed by sucking the cellular fluids of siphonal green algae and other macroalgae. These animals succeed in sequestering chloroplasts and chemical substances of the algae which they feed on, reusing them for their benefit. Indeed, some species maintain active sequestered chloroplasts for periods that can vary from a few hours to several months (Marín \& Ros, 1989a). Moreover, these gastropods transform and reuse the toxic chemical substances, obtained from the seaweeds which they feed on, as a defence against predators (Cimino \& Ghiselin, 1998).

According to Clark (1994), sacoglossans seem to have a role as regulatory species towards the benthic primary producers in the marine communities, controlling their abundance and occurrence. Consequently, it is fundamental to know what and when species are present in a given area for a correct evaluation of the marine ecosystems.

Recently, Lombardo \& Marletta (2020) produced the first list of the species of marine Heterobranchia present along the central-eastern coast of 
Sicily. From this list, it can be noted that in this area there are 14 species belonging to the super-order Sacoglossa. However, the data reported by Lombardo and Marletta (2020) provide only information on the presence and on the bathymetric range of the Sacoglossan species found in the study areas, without giving any information on the biology of these species. Therefore, the present research performs a complementary role, providing information about observations made by the authors throughout the years of study and updating, with the addition of two species (new for the examined areas), the list of sacoglossans along the central-eastern coast of Sicily.

\section{MATERIAL AND METHODS}

The present study was carried out between 2017 and the first months of 2021 in five sites located along the central-eastern coast of Sicily (Italy). These sites were selected based on different environmental conditions. For the area of Catania, two stations were examined: “Ognina" $\left(37^{\circ} 31 ' 50.4\right.$ ”N $\left.-15^{\circ} 07^{\prime} 10.8^{\prime \prime} \mathrm{E}\right)$ and "Bellatrix" $\left(37^{\circ} 32^{\prime} 03.2^{\prime \prime} \mathrm{N}-15^{\circ} 07^{\prime} 35.2^{\prime} \mathrm{E}\right)$, which present similar environmental conditions. Both areas are characterized by a strong anthropic impact, due to the presence along the coastline of apartment buildings and bathing establishments. Moreover, in close proximity, there is a collector and a touristic harbour. In the area of Santa Tecla, two stations were studied: "Scalo Pennisi" (37³8'23.2"N - 1511' 04.6"E) and "Acque Fredde" (37 $38^{\prime} 15.7^{\prime \prime} \mathrm{N}-$ $15^{\circ} 10^{\prime} 52.1$ "E). Also these two sites present similar environmental conditions, being the most natural among the studied areas. The last examined station was Santa Maria La Scala $\left(37^{\circ} 36^{\prime} 46.5^{\prime \prime} \mathrm{N}\right.$ $15^{\circ} 10^{\prime} 31.4$ " E) located in the immediate vicinity of the homonymous hamlet. This last area presents intermediate environmental conditions between the stations sited in Catania and those located in Santa Tecla. For practical reasons, the stations located in Catania were considered as a single site named "Catania" and the same consideration was made for the stations located in Santa Tecla.

Throughout the years of study, 322 scuba dives (124 in Catania, 102 in Santa Maria La Scala and 96 in Santa Tecla) were performed between 9:00 and 11:30 a.m., twice a week (marine-weather conditions allowing). For each examined site, the same underwater path was followed, according to the seabed geomorphology (nearly always between 0 and $45 \mathrm{~m}$ of depth). Data were collected through the "photographic capture" technique: during each scuba dive, all the encountered sacoglossans were photographed through an Olympus TG-4 underwater camera. Subsequently, the photos were examined and information regarding the species, the depth, the substrate, the period of the year, and any further observations were registered.

For the identification of Sacoglossan species, the following texts were mainly consulted: Schmekel \& Portmann (1982) and Trainito \& Doneddu (2014). Regarding the identification of phytobenthos, the algal species were examined in the laboratory using the identification keys of Cormaci et al. (2012; 2014; 2017 ; 2020). For each Sacoglossan species included in this study, the following information is provided: Morphology, Abundance, Location and depth, Substrates and habitats, Seasonality, Remarks.

\section{RESULTS}

Superorder SACOGLOSSA

Family OXYNOIDAE Stoliczka, 1868 (1847)

\section{Lobiger serradifalci (Calcara, 1840) (Figs. 1-4)}

MORPHOLOGY. The specimens showed a greenish colouration, sometimes almost yellowish, uniformly distributed along the body. The shell, of the same colour of the body, presented white bright spots along the edges. The biggest individuals had the body covered by bright white pointed protrusions, while smaller and medium-sized specimens had a completely smooth tegument. The parapodia of the biggest specimens presented pinkish dorsal edges, nearly always joined together. Instead, the parapodia of smaller specimens were always smooth, stumpy and flattened, white at the top. The small-sized specimens had often the head retracted within the shell (excluded the rhinophores).

ABUndDANCE. During this study, a total of 12 specimens was found, thus, this species can be considered uncommon.

LOCATION AND DEPTH. Lobiger serradifalci was found in Santa Maria La Scala and Santa Tecla, between 5 and $18 \mathrm{~m}$ of depth.

SUBSTRATES AND HABiTATS. This species was observed almost exclusively above or nearby the green alga Caulerpa cylindracea Sonder that was often 
surrounded (or embedded) from tufts of Halopteris scoparia (Linnaeus) Sauvageau. Rarely, this mollusc was found among turfs of Jania sp., Lophocladia lallemandii (Montagne) F. Schmitz and Ellisolandia elongata (J. Ellis \& Solander) K. R. Hind $\&$ G. W. Saunders; regardless always near thalli of C. cylindracea.

SEASONALITY. Lobiger serradifalci was always observed between July and October.

REMARKS. Almost all the specimens of $L$. serradifalci, found during this study, presented a strong sciaphilous behaviour. Indeed, they were often detected among thalli of $H$. scoparia. This attitude makes $L$. serradifalci one of the most difficult Sacoglossan species to found in this area, although it is probably more common than supposed. Rarely, if removed from the substrate, some specimens tend to "swim" for just a few seconds, rhythmically flapping their parapodia like wings.

Oxynoe olivacea Rafinesque, 1814 (Figs. 5, 6)

Morphology. The body presented a uniformly green, emerald coloration. On the rhino- phores and the dorsal part of the tail, there were evident yellow and blue spots. The distal part of each rhinophore had a beige ring. The shell was covered by little white dots and was almost completely hidden by parapodia. In some parts of the body, as the edges of parapodia and the dorsal part of the tail, pointed protrusions could be present.

ABUndance. During this study, only two specimens were found, thus, this species can be considered rare.

LOCATION AND DEPTH. Oxynoe olivacea specimens were only found in Santa Tecla, between 6 and $7.5 \mathrm{~m}$ of depth.

SUBSTRATES AND HABITATS. Oxynoe olivacea was always found on thalli of $C$. cylindracea, surrounded by small thalli of the following algae: H. scoparia, Jania sp. and Feldmannophycus rayssiae (Feldmann \& G.Feldmann) H. Augier \& Boudouresque.

SEASONALiTy. From July to August.

REMARKS. The two specimens were found in well-lit and open environments.
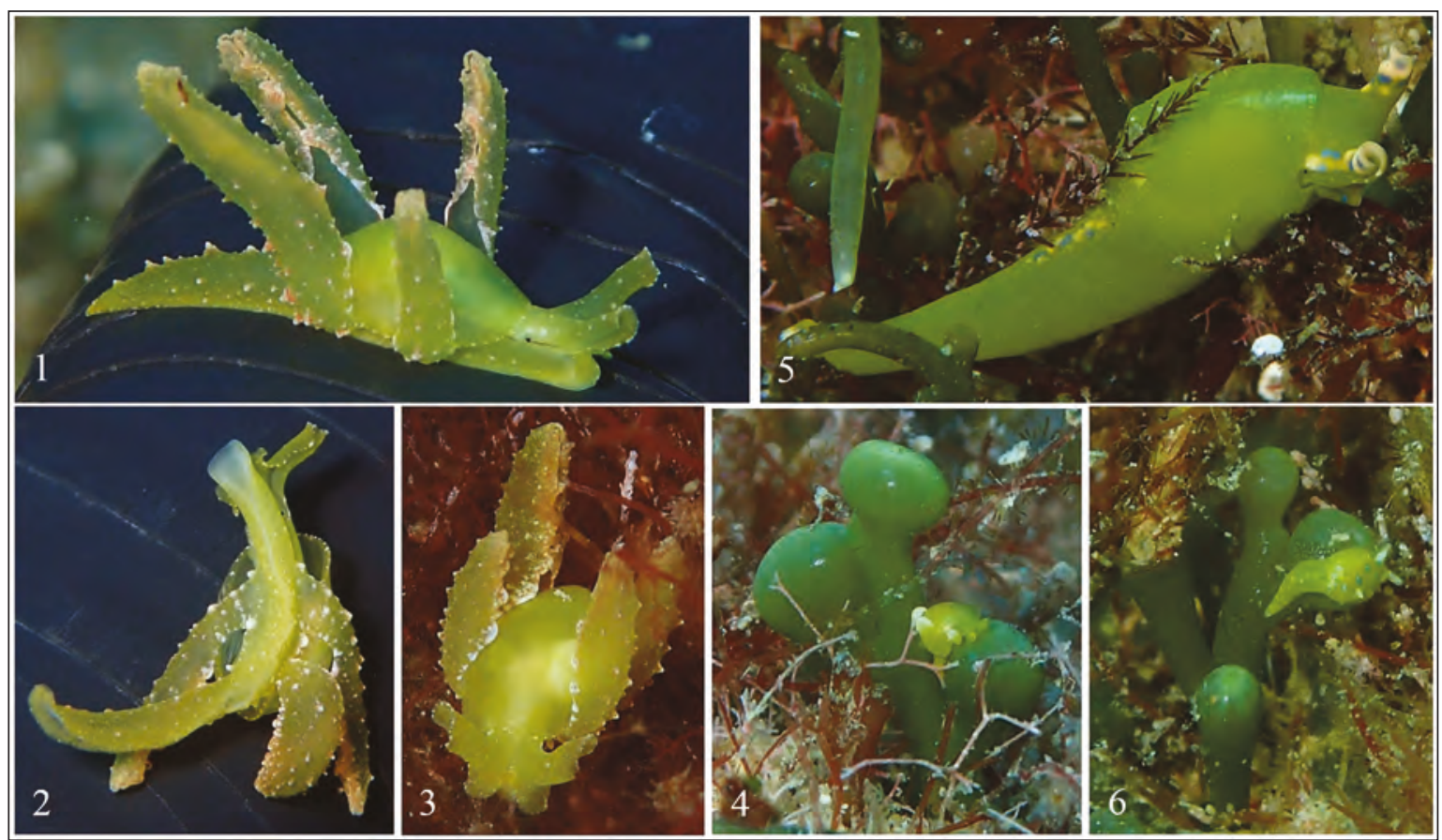

Figures 1-4: Lobiger serradifalci. Fig. 1: right lateral view. Fig. 2: ventral view. Fig. 3: antero-lateral view. Fig. 4: a tiny specimen on C. cylindracea. Figures 5, 6: Oxynoe olivacea. Fig. 5: right latero-dorsal view. Fig. 6: a small specimen on $C$. cylindracea (photos by A. Lombardo). 
Family PLAKOBRANCHIDAE Gray, 1840

\section{Bosellia mimetica Trinchese, 1891 (Figs. 7-9)}

MORPHOLOGY. This species presented two shapes of the body according to the substrates, on which it rested. Usually, when the animal was on its typical substrate, the green alga Halimeda tuna (J. Ellis \& Solander) J. V. Lamouroux, it assumed a flattened dorso-ventral shape, resembling a segment of this alga. When $B$. mimetica had this aspect, a network of vessels was easily detectable on the dorsum. Instead, when the animal was found on different substrates, it had an elongated habit of the body, resembling the typical slug shape. Generally, this species presented a green colouration, often with white blotches scattered along the surface of the body. Along the edges of the body, there were bright white dots. Some specimens could be completely white or with a gradient from green to white. Rhinophores were short and stumpy with a brown band near the tips.

ABundance. Bosellia mimetica was common in almost all the studied areas (Lombardo \& Marletta, 2021).
LOCATION AND DEPTH. This species was found in all the studies areas between 13.6 and $39.4 \mathrm{~m}$ of depth (Lombardo \& Marletta, 2021).

SubStRATES AND habitats. Bosellia mimetica was nearly always found on $H$. tuna. Rarely, it was detected on: Flabellia petiolata (Turra) Nizamuddin 1987, C. cylindracea Sonder, Dictyota dichotoma (Hudson) J. V. Lamouroux, D. implexa (Desfontaines) J. V. Lamouroux, Laurencia sp., Radicilingua sp., turf-forming Rhodophyta, Rhodymenia pseudopalmata (J. V. Lamouroux) P. C. Silva, tunicates and briozoans (Lombardo \& Marletta, 2021).

Seasonality. In the study areas, this species was present almost all-year round, with an evident occurrence from spring to summer, and a decline from the end of summer to autumn. Some rare specimens could be found in winter. The egg masses were observed all-year round, except in January (Lombardo \& Marletta, 2021).

Elysia flava Verrill, 1901 (Figs. 10, 11)

MoRPHOLOGY. The body presented a light green colouration. Along the edge of each parapodium
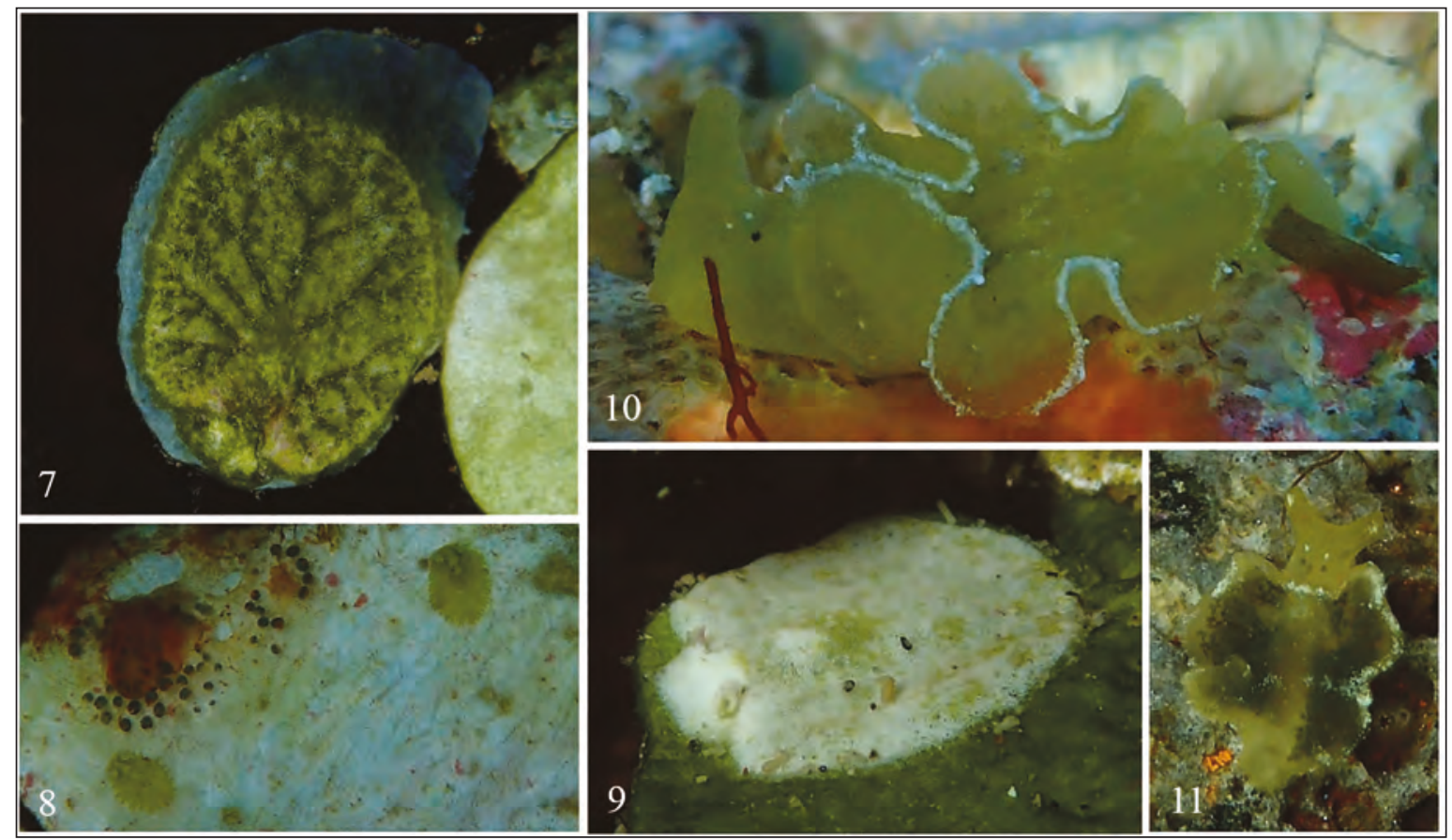

Figures 7-9: Bosellia mimetica. Fig. 7: dorsal view. Fig. 8: two small specimens. Fig. 9: a white specimen. Figures 10, 11: Elysia flava: Fig. 10: lateral left view. Fig. 11: dorsal view of a tiny specimen (photos by A. Lombardo). 
there were small white papillae, which were connected by a whitish line. On the external and internal surfaces of the parapodia there were small scattered white spots. The two found specimens presented dimensional and chromatic differences. The biggest one had in front of each eye two white dots, while in the smallest one there was only one dot. Moreover, the smallest specimen presented the tips of rhinophores whitish-coloured and through the tegument of parapodia it was possible to see a dense dark green network.

ABundance. During this study, only two specimens were found, thus, it can be considered a rare species.

LOCATION AND DEPTH. The two specimens of $E$. flava were found both in Santa Maria La Scala, one at $6.4 \mathrm{~m}$ and the other one at $9.2 \mathrm{~m}$ of depth.

SUBSTRATES AND HABITATS. Both specimens were observed beneath rocks, on which there were sponges, bryozoans and small fragments of brown and red seaweeds.

SEASONALity. The individuals were seen in June and July.

REMARKS. These findings represent the first report of E. flava along the central-eastern coast of Sicily. It is likely that the two observed specimens were in reality only one specimen found twice for two months. Indeed, these two specimens were both found beneath rocks that were located within a few meters from each other.

\section{Elysia hetta Perrone, 1990}

(Figs. 12, 13)

MoRPhOlOGY. The body had a general dark green colouration, and it was covered by bright blue, red and yellow spots. The head presented an evident white blotch, which continued posteriorly on the back until the tail. In some specimens, this white blotch cannot be present in the middle of the back. In bigger specimens there were whitish papillae along the edges of the parapodia. Regardless, the found specimens were all small-sized $(<5 \mathrm{~mm})$.
ABUndANCE: During this study, a total of 12 specimens was found, thus, it can be assumed that this species is uncommon.

LOCATION AND DEPTH. Elysia hetta was found in Santa Maria La Scala and Catania between 18.7 and $33.7 \mathrm{~m}$ of depth.

SUBSTRATES AND HABITATS. All specimens were observed beneath the green alga $H$. tuna .

SEAsOnAlity. In the examined areas, E. hetta was present in March, April, May and July.

REMARKS. During this study, some specimens, considered as $E$. hetta, were found with intermediate features between this species and Elysia margaritae Fez, 1962 (=Elysia gordanae T.E. Thompson et Jaklin, 1988) (Figs. 14, 15).

Recently, Ballesteros et al. (2021) highlighted how it is likely that the original description of E. hetta is based on juveniles of E. margaritae. If this hypothesis would be confirmed, all the specimens detected during this study and considered as E. hetta, could be juvenile forms of E. margaritae.

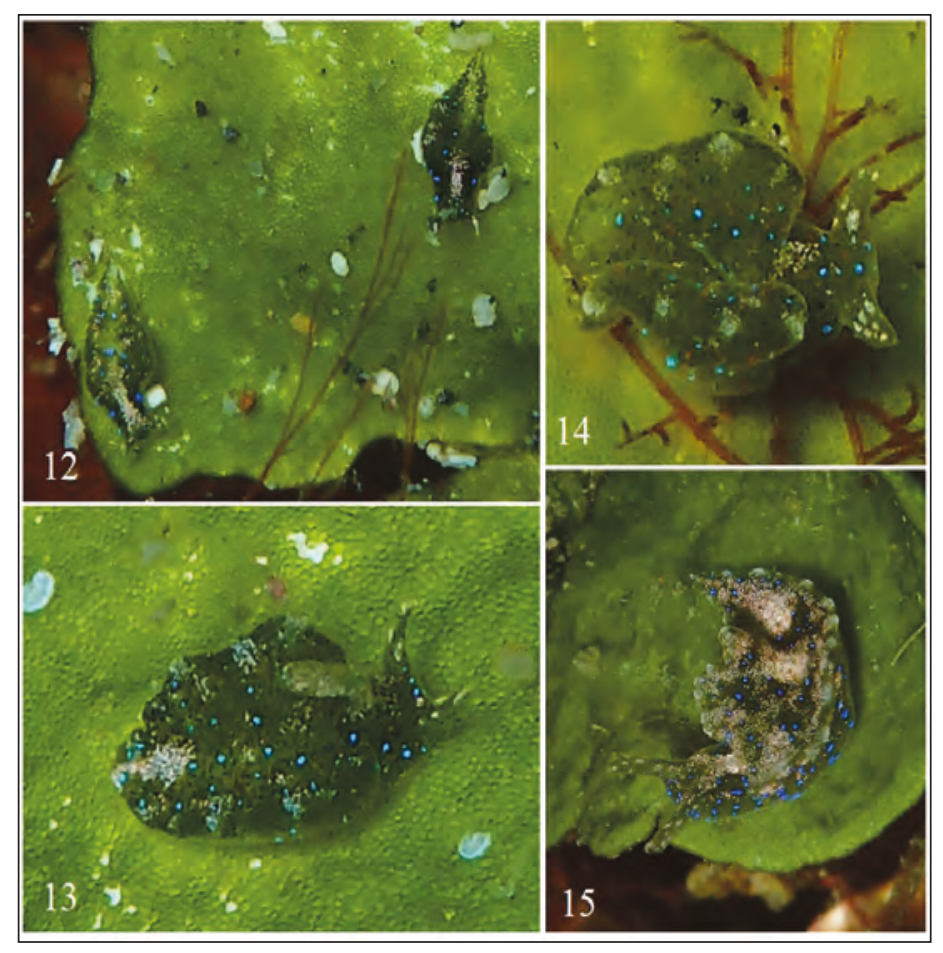

Figures 12, 13: Elysia hetta. Fig. 12: two specimens on H. tuna. Fig. 13: right latero-dorsal view. Figures 14, 15: intermediate specimens. Fig. 14: right latero-dorsal view. Fig. 15: dorsal view (photos by A. Lombardo). 


\section{Elysia margaritae Fez, 1962 (Figs. 16-18)}

MoRPHOlOGY. The specimens encountered during this study presented a green background colouration that was covered by white stripes and blotches in most of the body. Dorsally, the specimens had a large white faded stripe, from the head to the tip of the tail. This stripe was not present in two dorsal regions connected between parapodia. In most of the specimens, on each flank of the body, there were several white blotches that formed a white stripe, which developed longitudinally until the point of the tail. The presence of the dorsal stripe and of the lateral ones created a green space in the area of the eyes. The edge of parapodia presented several and evident white papillae. Rhinophores had several white spots. In the larger specimens, the white part of the body could present strong pinkish nuances. Along the surface of the body, except of the edges of parapodia, there were

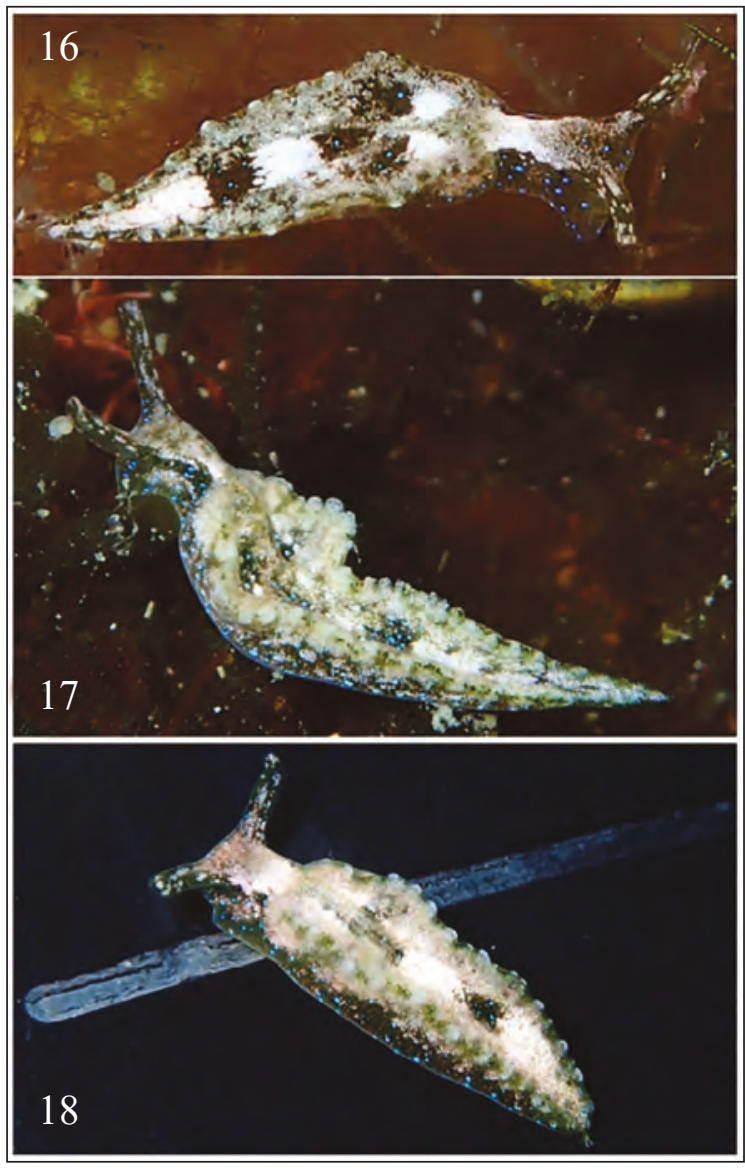

Figures 16-18: Elysia margaritae. Fig. 16: dorsal view. Fig. 17: left latero-dorsal view. Fig. 18: a specimen with evident pink nuances (photos by A. Lombardo). bright blue dots. In some specimens there were also red dots.

ABundance. During this study, about 20 specimens of E. margaritae were encountered, thus this species can be considered uncommon.

LOCATION AND DEPTH. Elysia margaritae was documented in Santa Maria La Scala and Catania between 9 and $26 \mathrm{~m}$ of depth.

SubStRATES AND HABitats. The specimens encountered during this study were found on different substrates: D. dichotoma; $D$. implexa; Zonaria tournefortii (J.V. Lamouroux) Montagne; H. scoparia; H. filicina (Grateloup) Kützing; Padina pavonica (Linnaeus) Thivy; Pterocladiella capillacea (S.G. Gmelin) Santelices \& Hommersand; Jania sp., which had diatoms and cyanobacteria as epiphytes; L. lallemandii; Peyssonnelia sp. and H. tuna.

Seasonality. From February to July.

REMARKS. If the hypothesis of Ballesteros et al. (2021) is correct (see above), thus, it is probable that $E$. margaritae spend the first stages of life exclusively on the green alga $H$. tuna and, once become larger, it achieves the ability to feed on other algae.

Elysia rubeni Martín-Hervás, Carmona, Jensen, Licchelli, Vitale et Cervera, 2019 (Figs. 19, 20)

Morphology. The individuals presented a green-coloured body. Along all the surface of it, there were several yellow spots and big bright blue dots. Rhinophores were grey/white and presented blue-violet tips.

ABUndANCE. During this study, a total of 19 specimens of $E$. rubeni was found. It can be considered an uncommon species.

LOCATION AND DEPTH. The individuals were found in all the examined areas, between 3.9 and $21.6 \mathrm{~m}$ of depth (Gerovasileiou et al., 2020; present study).

SubStRATES AND HABITATS. Elysia rubeni was observed on the following substrates: $H$. scoparia; $Z$. tournefortii; turfs of filamentous red algae, calcareous red algae (Gerovasileiou et al., 2020); $H$. tuna; F. rayssiae; Peyssonnelia sp.; Dictyopteris lucida M. A. Ribera Siguán, A. Gómez Garreta, Pérez Ruzafa, Barceló Martí \& Rull Lluch and turfs of 
Jania sp., covered by diatoms and cyanobacteria (present study).

Seasonality. This species was found from December to July and in November (Gerovasileiou et al., 2020; present study).

REMARKs. Two specimens were photographed during the breeding activity in February 2021.

\section{Elysia timida (Risso, 1818) (Figs. 21-24)}

MORPHOLOGY. The body was white with red dots scattered on the surface. The dorsal part surrounded by parapodia and the internal surface of them had a dark green, almost black, colouration. Nearly all specimens presented green veins on either side of the body, of rhinophores and on flanks.

ABundance. This species is very common in Santa Tecla and especially in Catania, where it was difficult not to see it. On the contrary, Santa Maria La Scala was the only site among those studied, where E. timida can be considered uncommon or even rare.

LOCATION AND DEPTH. This species was present in all the examined areas between 3.8 and $18.3 \mathrm{~m}$ of depth.
Substrates AND habitats. Mainly, the substrates/habitats on which large assemblages of $E$. timida were found are turfs of Jania sp., strongly covered by diatoms (Fragilaria sp., Coscinodiscus sp., Licmophora sp.) and cyanobacteria. Among these turfs there were also isolated thalli of green algae Chaetomorpha cf. ligustica (Kützing) Kützing and Pseudochlorodesmis furcellata (Zanardini) Børgesen. Single specimens were reported on the following substrates: H. scoparia; D. dichotoma; $D$. implexa; P. pavonica; turf of E. elongata; Ceramium sp. and nude rock.

Seasonality. Elysia timida was present throughout the year in Catania and Santa Tecla. In Catania from October to January, on average more than 30 specimens per dive were found, while during the rest of the year this number descended to $10-15$ individuals. Between July and October, this number decreased to 5 specimens per dive. In this site, the breeding activity was documented in January, May, July, August and November. In Santa Tecla, during the year, an average of 5 specimens per dive was observed. In this site, the reproductive activity was documented in February and July.

REMARKS. In literature, it is reported that E. $t i-$ mida lives mainly in environments rich of the green
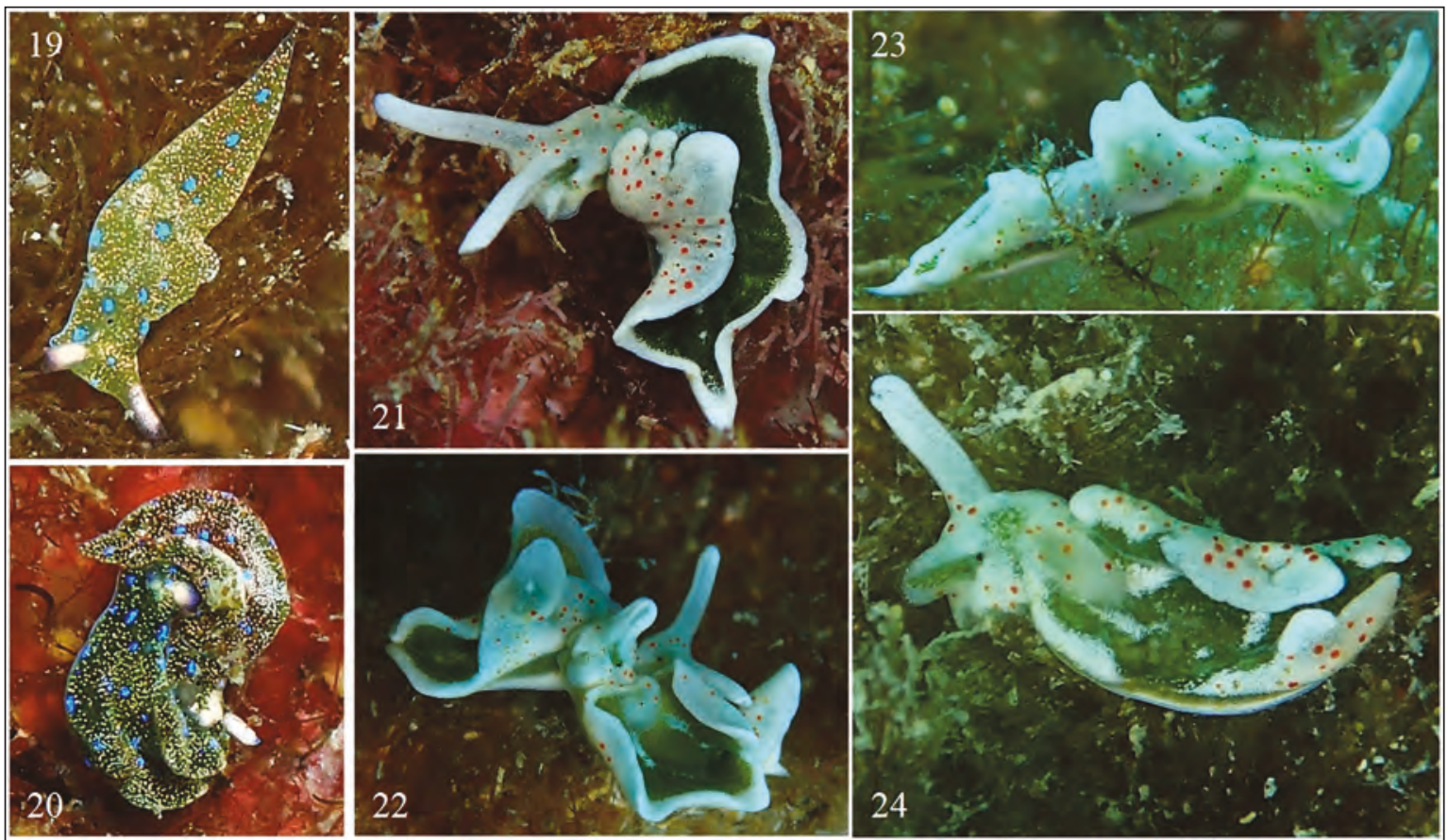

Figures 19, 20: Elysia rubeni. Fig. 19: dorsal view. Fig. 20: breeding activity. Figures 21-24: Elysia timida. Fig. 21: left laterodorsal view. Fig. 22: breeding activity. Fig. 23: right lateral view. Fig. 24: an injured specimen (photos by A. Lombardo). 
alga Acetabularia acetabulum (Linnaeus) P. C. Silva, which this mollusc feeds on (Marín \& Ros, 1989b). During the present research, no specimens of E. timida were found above or near this alga. It is interesting to highlight how in Catania and in Santa Tecla thalli of A. acetabulum were not detected, while in the site where E. timida seems to be a rare species (Santa Maria La Scala), some thalli of this alga were documented. Consequently, in the studied areas, it seems evident how this mollusc feeds on other macroalgae. Since almost all specimens were found in assemblages among turfs of Jania sp., covered by diatoms, it is possible that this Sacoglossan feeds on diatoms or rare green algae, which can be found scattered on these turfs, as those abovementioned. Some observed specimens presented missing parts and injuries due to possible attacks of a hypothetical predator.

\section{Elysia translucens Pruvot-Fol, 1957 (Figs. 25-27)}

MORPHOLOGY. Body emerald/light green, sometimes the tegument was almost transparent. Along the flanks and on the head, there were small bright blue dots. Each eye was almost completely sur- rounded by a white-yellow blotch. The tip of each rhinophore presented small white dots that could form a band. The edge of each parapodium showed several white spots that formed a stripe.

ABundance. Throughout this study, only three specimens of this species were found, thus, it can be considered rare.

LOCATION AND DEPTH. Elysia translucens was found in Santa Maria La Scala and Santa Tecla, between 6.8 and $7.5 \mathrm{~m}$ of depth.

SubStRATES AND habitats. This species was reported on the following substrates: H. scoparia; $D$. implexa; C. cylindracea; tufts of Ceramium sp. and F. rayssiae.

Seasonality. The specimens of E. translucens were documented in May, July and November.

Elysia viridis (Montagu, 1804) (Figs. 28-31)

MORPHOLOGY. The body presented a green coloration, and it was covered by many bright blue points. The rhinophores, the head, the back, the
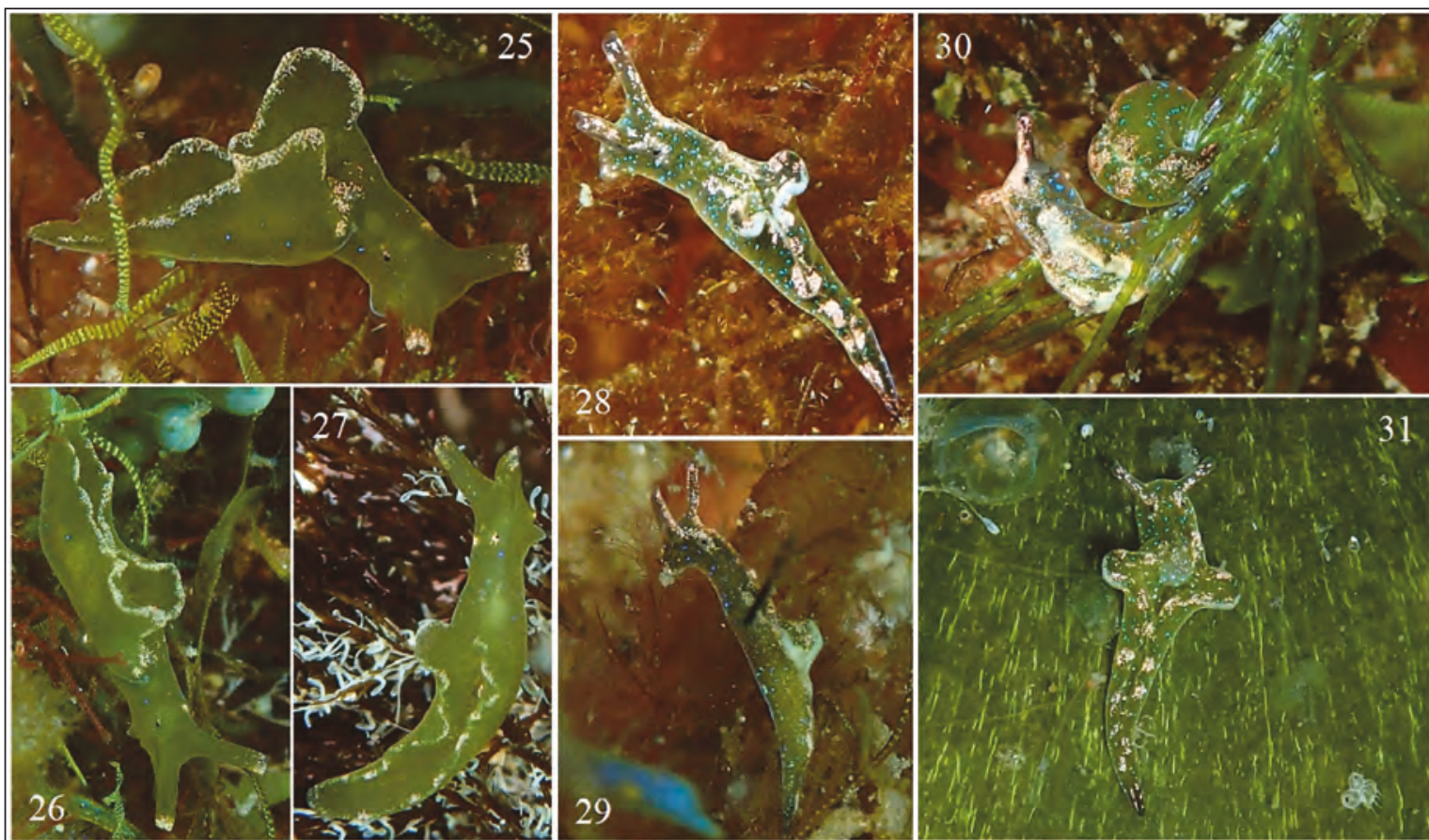

Figures 25-27. Elysia translucens. Fig 25: right latero-dorsal view. Fig. 26: dorsal view. Fig. 27: another specimen in dorsal view. Figures 28-31: Elysia viridis. Fig. 28: left latero-dorsal view. Fig. 29: lateral view. Fig. 30: two specimens close to each other. Fig. 31: dorsal view (photos by A. Lombardo). 
edge of parapodia and rarely the flanks were covered by a set of more or less numerous bright white dots. The tegument of the ocular area was usually grey. Almost all the specimens presented parapodia longitudinally contracted with a wing-shape.

ABundance. A total of nine specimens of this species was found during this study. E. viridis can be considered an uncommon species.

LOCATION AND DEPTH. Elysia viridis was observed in all the study areas examined in this study, between 7 and $20 \mathrm{~m}$ of depth.

Substrates AND Habitats. This species was found on the following substrates: H. filicina; $D$. dichotoma; D. implexa; F. rayssiae; turfs of Jania sp. covered by diatoms and cyanobacteria; Cladophora sp.; H. tuna and $F$. petiolata.

SEASONALITY. This mollusc was documented in January, March and from May to June.

\section{Thuridilla hopei (Vérany, 1853) (Figs. 32-37)}

MORPHOLOGY. Unmistakable. The head is blueazure and presented a white dorsal line, which sub- divided in two ones on the half of the head. Each of these lines reached the tip of rhinophores. On each side of the head there was a black line that could cover the eye. The rhinophores had a transverse black faded stripe in proximity of the tip. The parapodia showed externally several longitudinal bands more or less wide of different colours: yellow/white, black and blue-azure. The edges of parapodia had a yellow-orange colouration. The back was covered by parapodia and was black-coloured.

ABUndAnCE. This species was common in all the examined areas.

LOCATION AND DEPTH. Thuridilla hopei was observed between 3.7 and $34.5 \mathrm{~m}$ of depth, in all the study areas.

Substrates AND HABITATS. This species was found on different substrates, either on algae or animals (briozoans and sponges): Ceramium sp.; turfs of Jania sp. strongly covered by diatoms and cyanobacteria; turfs of Centroceras clavulatum (C.Agardh) Montagne; Champia parvula (C.Agardh) Harvey; turfs of Spyridia filamentosa (Wulfen) Harvey; Peyssonnelia sp.; Pterocladiella capillacea; Cladophora sp.; P. furcellata; Bryopsis

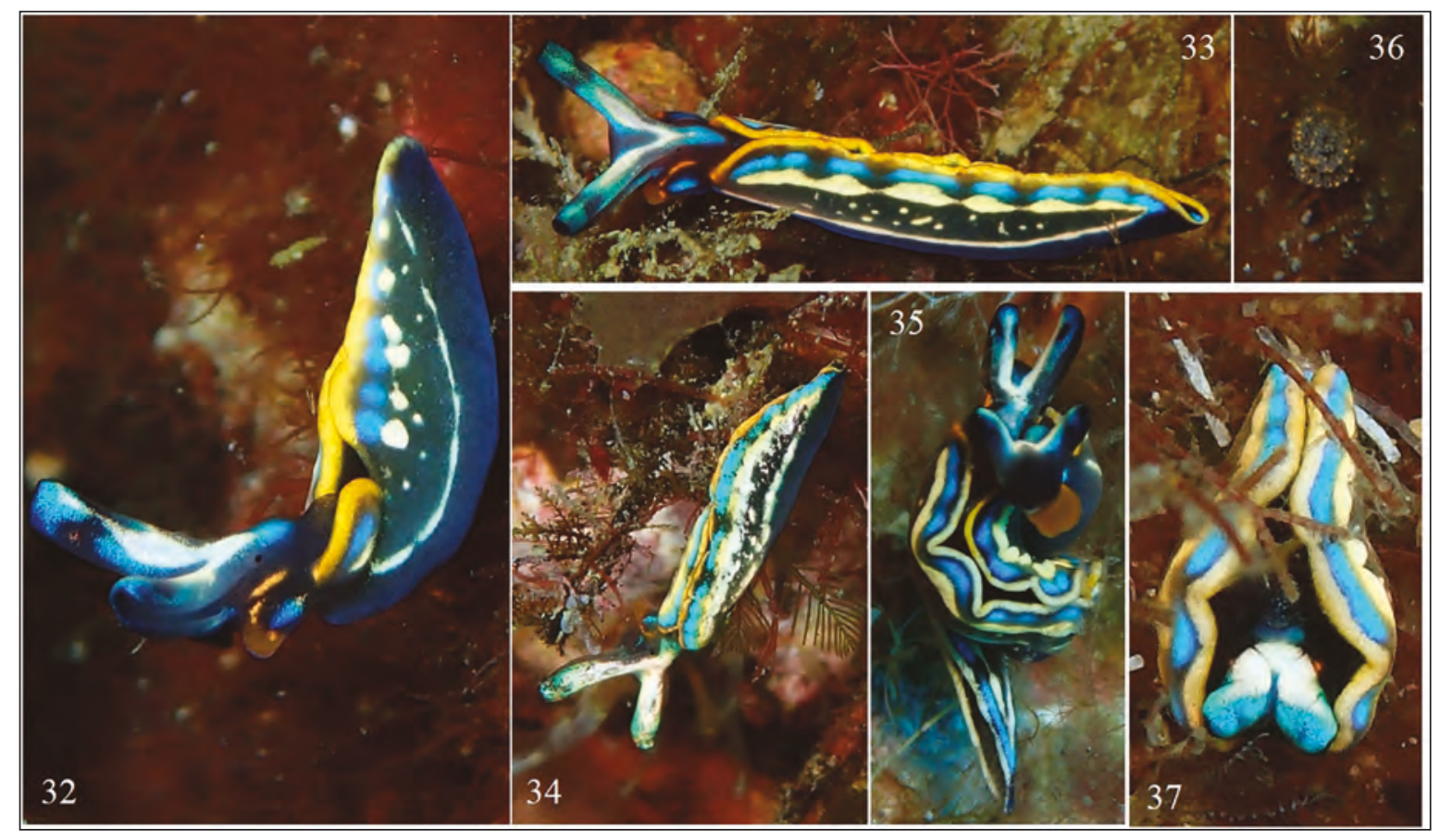

Figures 32-37. Thuridilla hopei. Fig. 32: left lateral view. Fig. 33: dorsal view. Fig. 34: a faded specimen. Fig. 35: reproductive activity. Fig. 36: an egg mass. Fig. 37: a contracted specimen (photos by A. Lombardo). 
plumosa (Hudson) C. Agardh; H. filicina; D. implexa; Z. tournefortii; Crambe crambe (Schmidt, 1862); Myriapora truncata (Pallas, 1766) and Reptadeonella violacea (Johnston, 1847).

SEASONALITY. In each examined site, T. hopei had generally two presence peaks (an average of 10 or more specimens per dive) throughout the year. These peaks were different for each site. In Santa Maria La Scala these peaks happened in March-April and July. In Santa Tecla these spikes were observed in December-January and August-September, while in Catania they were in June-July and November-January. Consequently, T. hopei could be present throughout all the seasons of the year. Regarding the breeding activities, they were documented in October at Santa Maria La Scala, in August at Santa Tecla and in January and November at Catania. Only a spawn was found in Santa Maria La Scala in April.

REMARKS. Throughout this study, some specimens were observed while they were caught by Calcinus tubularis (Linnaeus, 1767). Consequently, this crustacean could be a hypothetical predator of $T$. hopei as also shown by Rudman (2009). One specimen was contracted, when it was found, and its head was sunk between parapodia, probably in defensive position. This aspect could be caused by an attack of a possible predator, even if the specimen was perfectly undamaged. Moreover, rarely, specimens (both small and large-sized) showed a faded colouration with scattered white spots along the body. Furthermore, many encountered specimens presented the right side of the head red spotted. Probably, these specimens had bred since a short time. During the mating activities, the two involved specimens twisted around each other's bodies, maintaining contact between the genital apertures located on the right side of the head, as shown by Gascoigne (1985). The two involved specimens twisted around each other's bodies, maintaining contact between the genital apertures located on the right side of the head, as shown by Gascoigne (1985).

\section{Family LIMAPONTIIDAE Gray, 1847}

Ercolania coerulea Trinchese, 1892 (Figs. 38, 39)

MoRPhOlOGY. This species presented an almost transparent body, across which it was possible to see the greenish branches of the digestive gland in the cerata, in the head and in the rhinophores. The whole-body surface was covered by bright white dots. The rhinophores had white tips and the head was whitish with azure nuances. Each cerata presented a white-yellowish apex and the anterior surface was bright blue.

Abundance. During this study only one specimen was found. Consequently, it could be considered a rare species.

LOCATION AND DEPTH. The specimen was documented in the site of Santa Maria La Scala at 7.2 $\mathrm{m}$ of depth.

SUBSTRATES AND HABITATS. Ercolania coerulea was observed on a tangle formed by several red algae: Rhodymenia sp., Jania sp., C. parvula and L. lallemandii.

Seasonality. This species was only found in February.

REMARKS. This finding represents the first report of E. coerulea along the central-eastern coast of Sicily. The mollusc made "back and forth" rhythmical movements, similar to those commonly produced by E. timida.

Placida cremoniana (Trinchese, 1892) (Figs. 40, 41)

MoRPhOlOGY. This species presented the head, the flanks and the dorsal part of the back and tail black-coloured. Instead, the foot, the posterior side of rhinophores and the areas of eyes showed a greyish-cream colouration. Each cerata was orange, while the tip was black. On each flank, there was a thin orange line.

Abundance. During this study, only two specimens of this species were found. Therefore, $P$. cremoniana can be considered rare.

LOCATION AND DEPTH: Both specimens were detected in Catania, at 8 and $15.4 \mathrm{~m}$ of depth.

SubSTRATES AND Habitats. On turfs of Jania sp., densely covered by diatoms and cyanobacteria.

Seasonality. Placida cremoniana was found only in May.

\section{Placida viridis (Trinchese, 1874) (Figs. 42-44)}

MoRPHOLOGY. The body presented a transparent tegument, across which it is possible to observe several green branches of the digestive gland dis- 


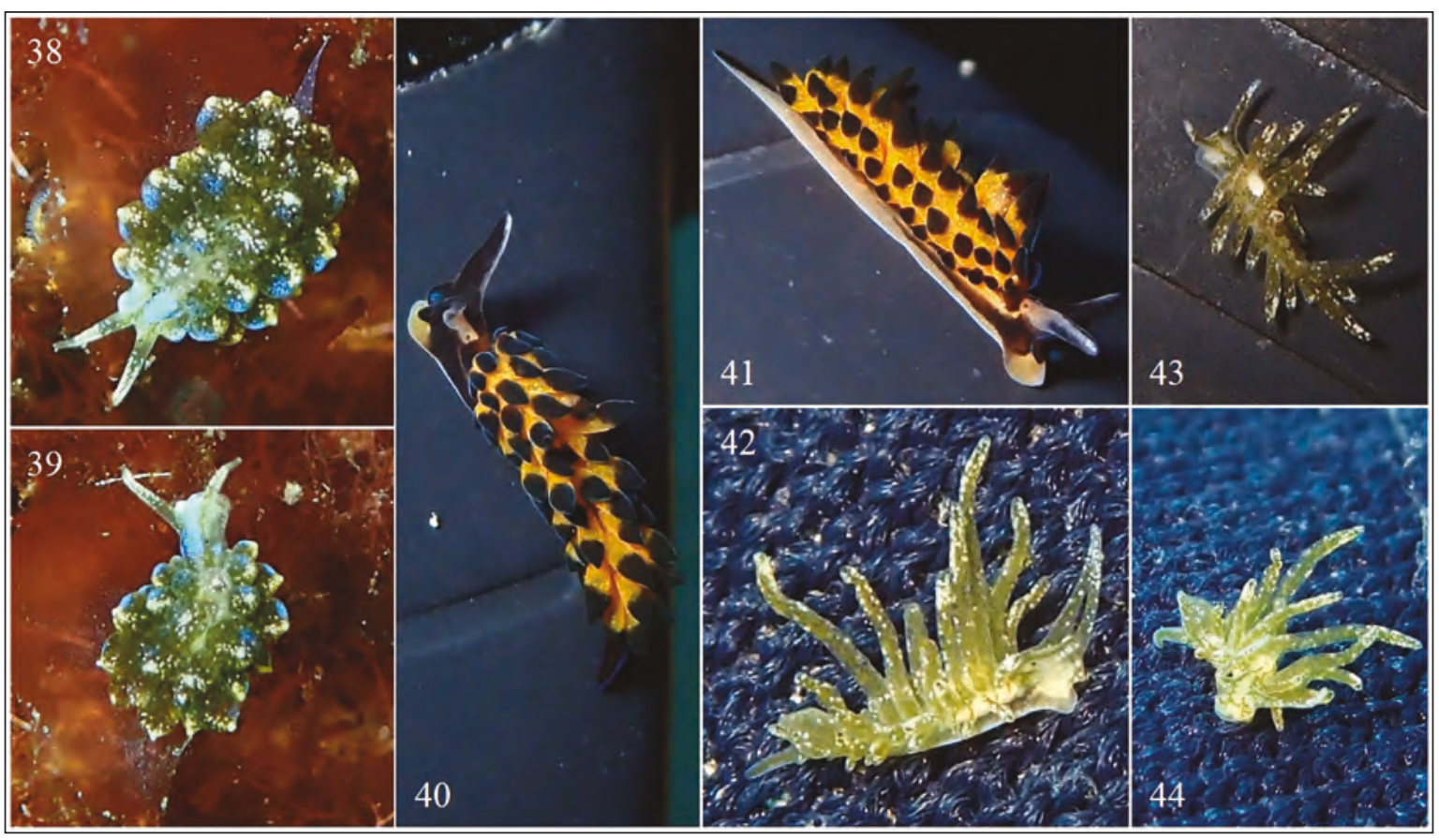

Figures 38, 39. Ercolania coerulea. Fig. 38: dorsal view. Fig 39: the same specimen while crawling. Figures 40, 41. Placida cremoniana. Fig. 40: left latero-dorsal view. Fig. 41: right lateral view. Figures 42-44. Placida viridis. Fig. 42: right lateral view. Fig. 43: dorsal view. Fig. 44: anterior view (photos by A. Lombardo).

tributed along almost all the body. The surface of tegument was covered by numerous scattered bright white dots. The apex of each cerata presented a small black dot. The area corresponding to the pericardium is white.

ABundanCE. During this study, only two specimens were found. Therefore, this species can be considered rare, but probably this rarity could depend on its small sizes and cryptic ability.

LOCATION AND DEPTH. Placida viridis was detected in Santa Maria La Scala and Santa Tecla, at 5.2 and $7.2 \mathrm{~m}$.

SuBSTRATES AND HABITATS. The specimens were observed on a thallus of $H$. scoparia and on a tangle of algae formed by Jania sp., F. rayssiae and B. plumosa.

Seasonality. Placida viridis was documented in August and October.

Remarks. Both specimens found throughout this study, when placed on artificial substrates in order to be photographed, became restless, speeding their movements. The bigger specimen encountered during this study, in this occasion moved spasmodically their cerata.
Family HERMAEIDAE H. Adams et A. Adams, 1854

Hermaea bifida (Montagu, 1816) (Figs. 45-48)

MorPHOLOGY. This species had a completely transparent body; thus, its internal parts were easily distinguishable. Usually, the specimens presented small bright white dots scattered along the body. They could be numerous or almost absent. The chromatic differences observed among the specimens were probably due to the diet. Indeed, two specimens showed a red digestive gland, two (of very small sizes) had an orange one, and only a specimen presented an apparently greyish one (see below). All the specimens presented a long tail.

ABundance. During this study, five specimens were found, thus, H. bifida can be considered rare, but probably it is more common that supposed (see below).

Location AND DEPTH. This Sacoglossan was documented in Santa Tecla and Catania, between 6 and $21.7 \mathrm{~m}$ of depth.

SUBSTRATES AND HABITATS. Hermaea bifida was found on the following substrates: Asparagopsis 
armata Harvey; F. rayssiae; D. dichotoma; D. implexa; Z. tournefortii and beneath a stone, covered by diatoms and cyanobacteria. A specimen was encountered while fluctuating, transported by the current, in the water column a few metres from the sea bottom.

Seasonality. Hermaea bifida was documented in January, February, March, July, August, and December.

REMARKS. It is important to highlight how the specimens encountered during this study presented evident chromatic differences in the digestive gland, based on the substrate where they were found. The individuals that were on red algae presented a red digestive gland, while those found on brown algae had an orange one. The only specimens found beneath a rock, covered by diatoms and cyanobacteria, presented a grey-coloured digestive gland and, overall, had the tegument probably covered by these organisms, which hid its real colouration. Consequently, it is very difficult to find this species, due to its small sizes, shape and colour. Therefore, it is highly probable that this species could be more or less common, but strongly cryptic.
Hermaea variopicta (A. Costa, 1869) (Figs. 49-51)

Morphology. Unmistakable. The body presented a violet-pinkish colouration and, on each flank and on the dorsal part of the tail, there was an orange line. These two lateral lines continued until the point of the head. The latter dorsally showed a set of lines of various colorations, which formed a pattern. Each eye was almost surrounded by a bright white stripe, which continued until the point of each rhinophore. Behind eyes, there was an orange line with a U-shape. Rhinophores were violet-pinkish and they, beyond the abovementioned white line, also presented a more or less visible orange line. On the middle of the back there was an evident white blotch with a circular shape. Each cerata presented a red colouration, and a drop shape with a crush in anterior-posterior direction. The edges of cerata showed some stripes constituted by several bright white dots, and the apices were orange. Overall, each cerata resembled a small flame.

ABundance. Throughout this study, only four specimens were found, thus $H$. variopicta can be considered a rare species.
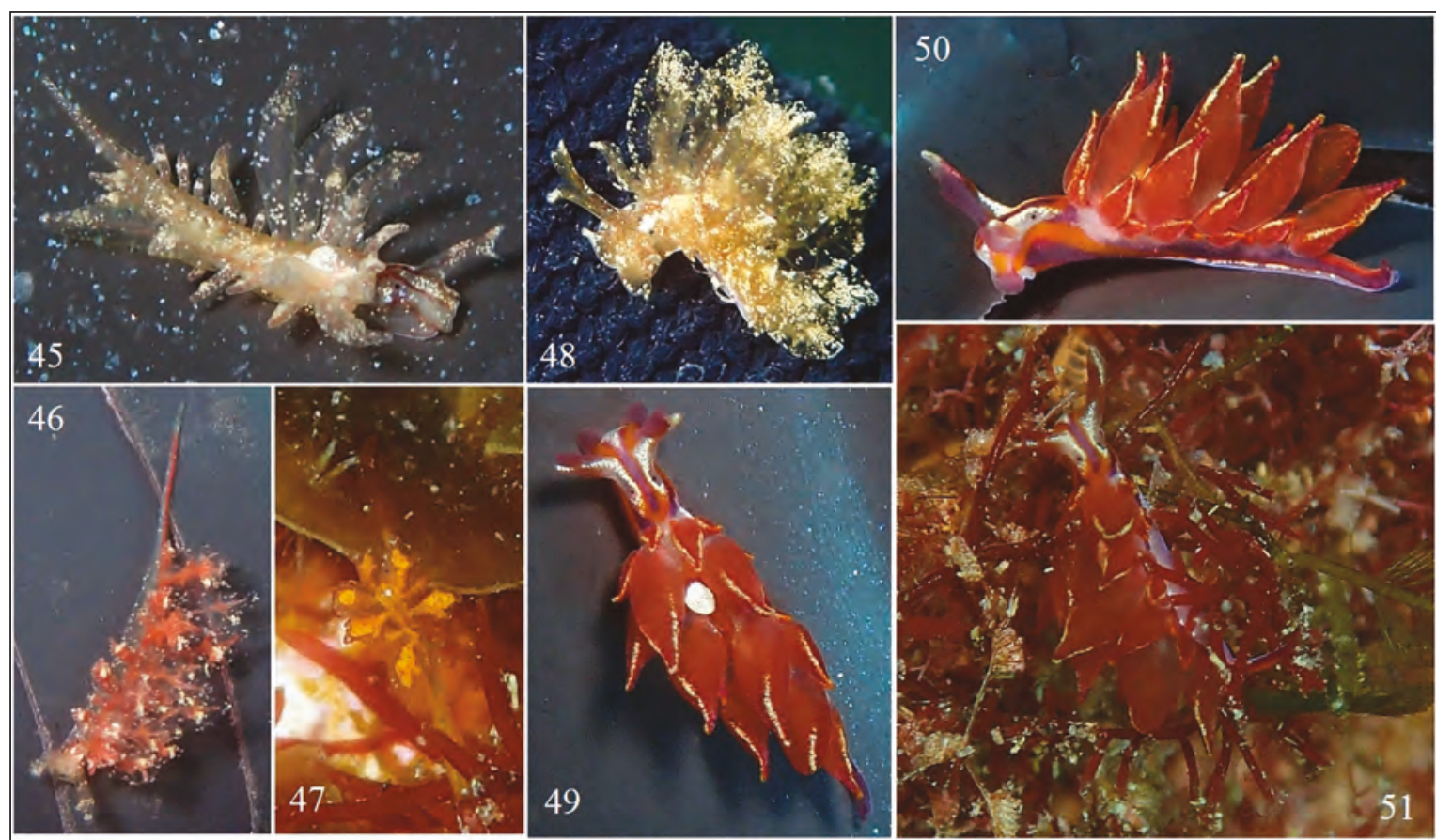

Figures 45-48. Hermaea bifida. Fig. 45: latero-dorsal view. Fig. 46: dorsal view. Fig. 47: a tiny specimen. Fig: 48: the specimen found beneath a rock covered by diatoms and cyanobacteria. Figures 49-51. Hermaea variopicta. Fig. 49: dorsal view. Fig. 50: left lateral view. Fig. 51: a specimen surrounded by algae (photos by A. Lombardo). 
LOCATION AND DEPTH. This species was documented in Santa Maria La Scala and Catania, between 7 and $21 \mathrm{~m}$ of depth.

SubSTRATES AND HabitATS. Hermaea variopicta was found on the following substrates: B. plumosa; $F$. rayssiae and beneath rocks covered by calcareous algae.

SeAsOnality. This sacoglossan was found in November, December and March.

REMARKS. As other species listed above, H. variopicta is a strongly cryptic species, thus, it is very difficult to observe, especially when it stays upon red algae. Therefore, it could be less rare than supposed.

\section{DISCUSSION AND CONCLUSIONS}

In the Mediterranean Basin (including the Black Sea) there is a total of 37 Sacoglossan species (Jensen, 2007). Through the present study, it was possible to observe that along the central-eastern coast of Sicily is present almost the $43 \%$ of all Mediterranean species. Considering the number of examined sites during this study, this percentage reflects a high level of biodiversity of these gastropods in this area. Indeed, it is important to highlight that, through this research it was recorded the presence of two Sacoglossan species (E. flava and $E$. coerulea), not previously reported in the list of Lombardo and Marletta (2020) and recorded for the first time in the central-eastern coast of Sicily. Consequently, it seems highly probable that increasing the number of examined sites along the central-eastern coast of Sicily, new and interesting discoveries on this peculiar group of molluscs could be disclosed.

\section{REFERENCES}

Ballesteros M., Madrenas E. \& Pontes M., 2021. "Elysia gordanae" in OPK-Opistobranquis. Published: 14/05/2012. Accessed: 01/03/2021. Available at (https://opistobranquis.info/en/IiP74).

Cimino G. \& Ghiselin M. T., 1998. Chemical defense and evolution in the Sacoglossa (Mollusca: Gastropoda: Opisthobranchia). Chemoecology, 8: 51-60.

Clark K. B., 1994. Ascoglossan (=Sacoglossa) molluscs in the Florida Keys: rare marine invertebrates at spe- cial risk. Bulletin of Marin Science, 54: 900-16.

Cormaci M., Furnari G., Catra M., Alongi G. \& Giaccone G., 2012. Flora marina bentonica del Mediterraneo: Phaeophyceae. Bollettino dell'Accademia Gioenia di Scienze Naturali, 45 (375): 1-508.

Cormaci M., Furnari G. \& Alongi G., 2014. Flora marina bentonica del Mediterraneo: Chlorophyta. Bollettino dell'Accademia Gioenia di Scienze Naturali, 47 (377): 11-436.

Cormaci M., Furnari G. \& Alongi G., 2017. Flora marina bentonica del Mediterraneo: Rhodophyta (Rhodymeniophycidae escluse). Bollettino dell'Accademia Gioenia di Scienze Naturali, 50 (380): 1-391.

Cormaci M., Furnari G. \& Alongi G., 2020. Flora marina bentonica del Mediterraneo: Rhodophyta - Rhodymeniophycidae I. Acrosymphytales, Bonnemaisoniales, Gelidiales, Gigartinales, Gracilariales. Bollettino dell'Accademia Gioenia di Scienze Naturali, 53 (383): 1-346.

Gascoigne T., 1985. A provisional classification of families of the order Ascoglossa (Gastropoda: Nudibranchiata). Journal of molluscan Studies, 51: 8-22. https://doi.org/10.1093/oxfordjournals.mollus.a065886

Gerovasileiou V., Akyol O., Al-Hosne Z., Alshikh Rasheed R., Ataç E., Bello G., Ćetković I., CorsiniFoka M., Crocetta F., Denitto F., Guidetti P., Gül B., Insacco G., Jimenez C., Licchelli C., Lipej L., Lombardo A., Mancini E., Marletta G., Michailidis N., Pešić A., Poursanidis D., Refes W., Sahraoui H., Thasitis I., Tiralongo F., Tosunoğlu Z., Trkov D., Vazzana A. \& Zava B., 2020. New records of rare species in the Mediterranean Sea (May 2020). Mediterranean Marine Science, 0: 340-359. https://doi.org/ 10.12681/mms.22148

Händeler K., 2010. Evolution of Sacoglossa (Opisthobranchia) with emphasis on their food (Ulvophyceae) and the ability to incorporate kleptoplasts. PhD Tesis, Rheinischen Friedrich-Wilhelms-Universität Bonn: $120 \mathrm{pp}$.

Jensen K.R., 2007. Biogeography of the Sacoglossa (Mollusca, Opisthobranchia). Bonner zoologische Beiträge, 55 (3-4): 255-281.

Lombardo A. \& Marletta G., 2020. The biodiversity of the marine Heterobranchia fauna along the centraleastern coast of Sicily, Ionian Sea. Biodiversity Journal, 11: 861-870. https://doi.org/10.31396/Biodiv.Jour.2020.11.4.861.870

Lombardo A. \& Marletta G., 2021. Contribution to the knowledge of Bosellia mimetica Trinchese, 1891 (Gastropoda Sacoglossa) and its seasonality along the central-eastern coast of Sicily (Ionian Sea). Biodiversity Journal,12 (2): 335-343.

https://doi.org/10.31396/Biodiv.Jour.2021.12.2.335.343

Marín A. \& Ros J.D., 1989a. The chloroplast-animal association in four Iberian Sacoglossan Opisthobranchs: 
Elysia timida, Elysia translucens, Thuridilla hopei and Bosellia mimetica. Scientia Marina, 53: 42-440.

Marín A. \& Ros J., 1989b. Los sacoglosos (Mollusca, Opisthobranchia) del sudeste iberico. Catalogo de las especies y presencia de cloroplastos algales en las mismas. Iberus, 8: 25-49.

Rudman W.B., 2009. (Jun 12). Comment on Re: Thuridilla hopei under predation attack by Dominique
Horst. [Message in] Sea Slug Forum. Australian Museum, Sydney. Available from http://www.seaslugforum.net/find/22520

Schmekel L. \& Portmann A., 1982. Opisthobranchia des Mittelmeeres. Nudibranchia und Saccoglossa. SpringerVerlag., Berlin, Germany, 410 pp.

Trainito E. \& Doneddu M., 2014. Nudibranchi del Mediterraneo. Il Castello, Cornaredo, Italy, 192 pp. 